\title{
THE INFLUENCE OF FINANCIAL KNOWLEDGE AND RISK TOLERANCE ON INVESTMENT DECISION MAKING
}

\author{
Muhammad Raihan Mubaraq* \\ Universitas Airlangga, Indonesia \\ Muslich Anshori \\ Universitas Airlangga, Indonesia \\ Huda Trihatmoko \\ Universitas Airlangga, Indonesia
}

\begin{abstract}
This study aims to provide empirical evidence of the effect of financial knowledge and risk tolerance on investment decision-making. This type of research is associated research with data collection methods using survey samples. Measurement of variables in this study uses a Likert scale from 1 for strongly disagree to a scale of 5 for strongly agree. The population in this study are investors who have attended the capital market school in the Indonesian Stock Exchange, West Nusa Tenggara Representative Office, and who had a single investor identification (SID). Sampling refers to the Slovin formula with a sample size of 110 respondents. Analysis of the data in this study using multiple linear regression analysis. The results of this study indicate that financial knowledge and risk tolerance affect investment decision-making. Implications of this study for investors to pay more attention to understanding in the form of financial knowledge and recognize the type of risk tolerance that exists in investors in making investment decisions in the capital market.
\end{abstract}

JEL: G11, G14, G32, G41

Keywords: financial knowledge, investment decision making, risk tolerance

\section{INTRODUCTION}

Investor participation in financial markets has increased sharply in recent times. Everyone invests in getting a better life in the future by maximizing wealth which provides a higher level of expected return than other investment opportunities. According to Calvet, Célérier, Sodini, \& Vallée (2016), the financial market offers the possibility of "making money" and getting a return on the invested capital, which is the reason investors increase. The flexibility offered from financial market instruments means that one can quickly liquidate the invested funds.

Figure 1. shows the growing phenomenon of single investor identification (SID) in the Indonesian Capital Market in 2020 of 3,61 million SID with a percentage increase of $45.51 \%$ compared to 2018. This number represents the number of single investor identification (SID) consolidated in the Indonesian Capital Market instruments (stocks, debt securities, mutual funds, state securities, and other securities). In addition, the daily stock trading frequency reached 392 thousand each day, which is the highest number in Southeast Asia, with investor activity reaching 43 thousand each day and 7,5 million transactions each day.

\footnotetext{
*Email : mraihanmubaraq@gmail.com

Received : 07-06-2021, Accepted : 27-08-2021, Published : 29-08-2021

P-ISSN : 2087-9954, E-ISSN : 2550-0066. DOI : http://dx.doi.org/10.26418/jebik.v10i2.47089
} 


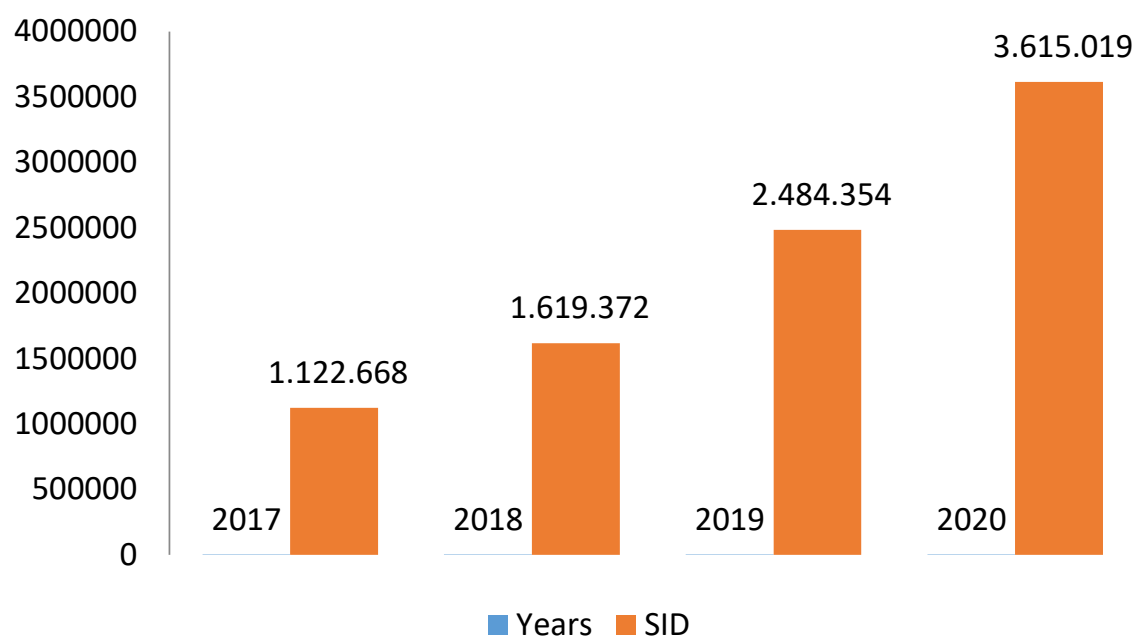

Sources: kseinews and www.ksei.co.id (Processed Data)

Figure 1. Growth in Total Number of SID (2017 - November 30, 2020)

Basically, people invest to get a better life in the future. Every investor who wants to maximize wealth will be attracted to an investment that provides a higher level of expected return than other investment opportunities. Investment is not only hoping to get a return from the financial side, but investment becomes meaningful for investors as a form of non-financial return. Investors tend to invest in companies with positive social contributions so that they feel comfortable with their investments. Decision makers strongly believe that they should avoid unethical gain. There are two types of investor behavior in making investment decisions, namely investors who are rational and irrational. Types of investors who are rational will make investment decisions based on their investment and financial knowledge, such as available information, level of profit, and level of risk. Investors who are irrational will make investment decisions based on several factors, namely psychological and demographic factors.

Financial knowledge is knowledge referring to what individuals know about their financial concepts (Marsh, 2006). Financial knowledge is divided into objective and subjective. Investors with objective financial knowledge are more likely to be analytical when making decisions than investors with subjective finances that involve instinct (Wang, 2009). Practices in financial knowledge are growing and are closely related to everyday life, such as how to use the income earned and manage the income for investment or for daily life. Financial knowledge has a close relationship with financial literacy or financial education.

Another factor that determines investors in making investment decisions is risk tolerance. Risk tolerance is an investor's ability to invest in varying amounts over a long period. Investors tend to have a higher risk tolerance than investors who do not invest in investment decisions in the capital market (Falahati \& Paim, 2012). Financial risk is the desire or unwillingness to take an unwarranted part of the action taken. Risk is an uncertainty that gives rise to unwanted loss events, if the tolerance for risk is ignored, the planning and implementation can result in risks that are not in accordance with the risk profile. Investors have different levels of tolerance for their investments. Different people's tolerance for risk is caused by many factors, such as age, gender, education, and income. Risk-taking capacity varies from investor attitudes towards tolerable risk, namely the type of investor risk seeker, risk averter, or risk indifference (Bailey \& Kinerson, 2005). 
Previous research conducted by Akhtar \& Das (2019) mentions that financial knowledge influences investment decisions. The results of this study are in line with research conducted by Goldsmith \& Goldsmith (2016); and Baker, Kumar, Goyal, \& Gaur (2019). Kannadhasan (2015), in his research, states that investors who have little financial knowledge but intend to invest are more likely to take risks compared to investors who have sufficient knowledge. However, this contradicts the research conducted by Mazumdar (2014), which states that financial knowledge does not have a significant relationship with investment behavior. Wulandari \& Iramani (2014) mention indicates that risk tolerance affects investment decision-making. Falahati \& Paim (2012), in their research, revealed that risk tolerance tends to be high according to the gender and age of investors in determining investment instruments. At the same time, Duong \& Huong (2017) found that risk tolerance has a negative relationship with investors perceptions of risk in making investment decisions.

Lintner (1969) explains behavior finance theory as a process of how humans interpret and act on information to make investment decisions. Bodie, Kane, \& Marcus (2014) explained that there are two thoughts, first is that investors cannot always process data in the right way so that possibility of wrong predictions of future returns. Second, if the distribution is true, investors tend to make suboptimal decisions. This thinking strengthens investors can make decisions that are not right. Behavior finance is intended for decision making because it can be a factor driving market prices.

Financial knowledge and risk tolerance are very much needed in supporting investment in the capital market to avoid harmful transactions to make the right decisions. Having sufficient financial knowledge and knowing the limits of risk tolerance for investors can avoid fraudulent investments, such as in the case of stock price manipulation. According to Capital Asset Management, there was a case of stock price manipulation by PT. Sekawan Intripratama Tbk. (SIAP). This incident is a sign that the world of capital markets cannot be separated from fraud. The case from SIAP will affect potential investors, especially young people and beginners who are currently the target market to boost the investor base. This case will continue to occur if investors do not have adequate financial knowledge and risk tolerance of investment, thus making investors expect getting high returns.

This research will be conducted on stock investors who have attended the Capital Market School by the Indonesia Stock Exchange Representative Office of West Nusa Tenggara. At the same time, Community Savings Stock program as a pilot project for the Indonesia Stock Exchange because it is considered that Lombok Island has good economic potential. The selection at the Indonesia Stock Exchange for the NTB Representative Office was due to its relatively new presence, which was inaugurated on December 7, 2017. In addition, investors already have a single investor identification (SID). The reason is that stock investors are expected to be fully capable of having financial knowledge and knowing the risk limit they will accept (tolerance) from the investment activities carried out.

Based on the description above, a problem formulation can be drawn: Does financial knowledge and risk tolerance affect investment decision-making. This study aims to obtain empirical evidence of the influence of financial knowledge and risk tolerance on investment decision-making. In the future, it can be used as a reference for investors who want to invest in stocks in Indonesia. 


\section{LITERATURE REVIEW}

\subsection{The Effect of Financial Knowledge on Investment Decision Making}

Behavioral finance theory is about human actions and understanding and investor reasoning, including the decision-making process in which it influences the decision. Fuller (2000) explains behavior finance, a combination of classical economics and finance with psychology and decision-making science. Investors who make transactions tend to want to know and differentiate and ensure that they are not wrong in making decisions, so adequate financial knowledge is needed to avoid making investment decisions. In this study, behavior finance is seen from the psychology of investors in investment decisions making.

Financial knowledge can be influence investment decision-making because investors who have good financial knowledge can predict investments that will arise so that the investments taken can generate profits. Each individual's financial knowledge is different; this allows for different investment choices. High financial knowledge can help investors in determining which type of investment suits them.

Financial knowledge is one of the criteria used when making investment decisions. This is supported by research conducted by Akhtar \& Das (2019), which states that financial knowledge positively affects investment decisions. This condition shows the need for how much investors involve their knowledge to make investment decisions (Baker et al., 2019). Sahi, Arora, \& Dhameja (2013) stated that understanding individual investment decisions requires financial knowledge of various behaviors related to investor decision-making itself. Mazumdar (2014) researched by looking at the relationship between two factors, namely financial knowledge and risk preference on investment behavior which stated that there was no significant relationship between financial knowledge and investment behavior as well as risk preference which did not have a significant relationship with investment behavior. Wang (2009) research results mention that financial knowledge consists of two primary components, namely objective financial knowledge and subjective financial knowledge. The study results indicate that investors' subjective knowledge mediates objective knowledge of risk-taking when making investment decisions. Thus, based on the behavioral finance theory and previous research that has been described above, the following hypotheses can be built:

H1: Financial knowledge has a positive effect on investment decision making

\subsection{The Effect of Risk Tolerance on Investment Decision Making}

Behavioral finance theory combines classical economics and finance with psychology and decision-making science (Lintner, 1969). Risk tolerance, when viewed from the attitude of investors, there are three types of individual investors, namely risk seeker, risk-neutral, and risk averter. Investors are included in the type of risk seeker if the investor decides to choose the type of investment with a high risk. Investors are included in the risk-neutral type if the investor decides to choose the type of investment with the same profit level as the risk level. Investors are included in the type of risk averter if the investor decides to choose the type of investment with a low level of risk (Bodie et al., 2014). The level of tolerance of investors to various risks can be said that level of tolerance of investors influences decision making. 
The attitude of a person or investor in determining tolerance for their investment tends to be different according to the stock portfolio they have. Individuals who prefer lower investment risk tend to invest with a lower overall level of risk and those who prefer higher investment risk choose investments with a higher overall level of risk. Because of these differences, it can be said that the level of investor tolerance for risk has an influence on investment decision making.

Measuring the risk profile aims to determine the client's risk tolerance, namely the level of risk that the client/individual/investor is willing to bear in investing to get a certain return. Personal profiling is the process of using quantitative and qualitative assessment methods to obtain an accurate analysis of an individual's non-financial background in order to facilitate optimal financial planning.

Wulandari \& Iramani (2014) examine the effect of risk tolerance on economic lecturer's investment decision making. The results of this study indicate that risk tolerance affects investment decision-making. Falahati \& Paim (2012), in their research, revealed that risk tolerance tends to be high according to the gender and age of investors in determining investment instruments. At the same time, Duong \& Huong (2017) found that risk tolerance is negatively related to perceived risk. Risk tolerance directly affects risky investment instrument decisions (positive) and indirectly affects decisions through risk perception. Thus, based on the behavioral finance theory and previous research that has been described above, the following hypotheses can be built:

H2: Risk tolerance has a positive effect on investment decision making

From the explanation above, it can be described the influence of financial knowledge and risk tolerance on investment decision-making in a research framework as follows.

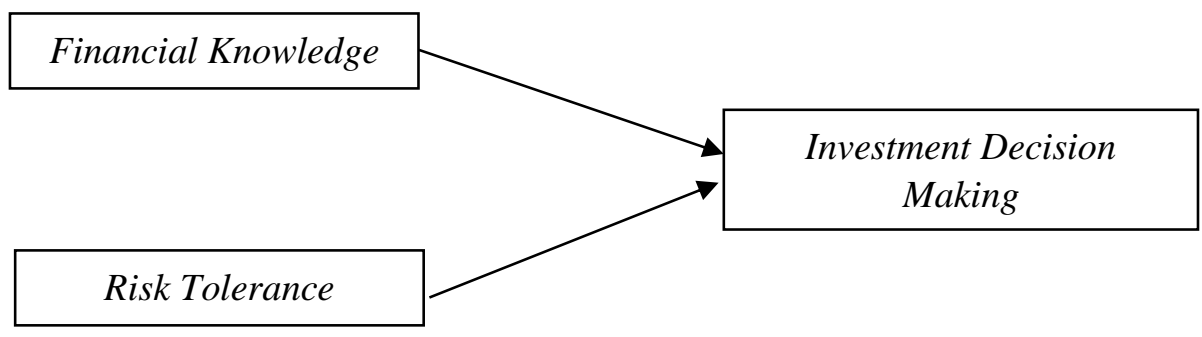

Figure 2. Research Framework

\section{METHODOLOGY}

This study uses primary data obtained using a questionnaire given to investors who have attended the Capital Market School at the Indonesia Stock Exchange Representative Office of West Nusa Tenggara and already have a single investor identification (SID) population. The number of registered investors as of July 2019 was 5,429 SID's, while based on Sub Securities Accounts (SRE), there were 5,983 investors. The sample size is determined by using the Slovin formula so that the number of respondents is 110 investors who will be sampled in this study. The data analysis technique used a questionnaire method. The questionnaire contains a list of statements related to financial knowledge variables containing 12 statements, risk tolerance containing 12 statements, and investment decision making containing ten statements. The assessment of the identified variables was carried out using a likert scale. Respondents who assessed with number 5, mean that the respondent's perception is very positive about the object being asked, if answering number 3 means neutral, and if answering on number 1 , the respondent's perception is very negative about the object being asked. 
Investment decision-making is a policy or decision taken to invest in one or more assets to gain profits in the future (Wattanasuwan, 2005). Investment decision-making is measured by Natapura (2009) using two indicators, namely rational decisions, and irrational decisions. Financial knowledge is information obtained through learning and organizing that is stored in memory (Wang, 2009). As measured by Alba \& Hutchinson (2000), financial knowledge has two indicators: knowledge of objective norms and knowledge of subjective norms. Risk tolerance is a person or investor's tolerance for the risks faced or accepted in investing. According to Grable \& Lytton (1999), risk tolerance has three indicators: risk seeker, risk-neutral, and risk averter.

The validity and reliability analysis in this study was conducted to ensure that the items on the financial knowledge, risk tolerance, and investment decision-making variables could measure the existing aspects. It is said to be valid if the statement can reveal what is measured by the questionnaire. If the correlation of each indicator is 0.30 and above, then the instrument is valid (Sugiyono, 2013). While a variable is said to be reliable if it gives a Cronbach Alpha value $>0.70$ (Ghozali, 2013). All indicators used to measure financial knowledge, risk tolerance, and investment decision-making variables are valid because the correlation of each indicator is 0.30 and above, and the calculated significance value is less than 0.05 . The financial knowledge variable has a Cronbach alpha of 0.783 ; risk tolerance of 0.750 ; and investment decision making of 0.785 . This means that all of these variables are eligible for further analysis.

The relationship between financial knowledge and risk tolerance for investment decisionmaking was analyzed using multiple linear regression. The variables in this study consisted of the dependent variable, namely investment decision making (Y). In comparison, the independent variables consisted of each $X_{1}$ and $X_{2}$. Also, variable control is $X_{3}$ until $X_{7}$. Which, in general, the model regression equation:

$Y=\alpha+\beta_{1} X_{1}+\beta_{2} X_{2}+\beta_{3} X_{3}+\beta_{4} X_{4}+\beta_{5} X_{5}+\beta_{6} X_{6}+\beta_{7} X_{7}+\varepsilon$

with :

$\mathrm{Y} \quad=$ Investment Decision Making

$\alpha \quad=$ Constant

$\beta_{1}-\beta_{7}=$ Variable regression coefficient $X_{1}-X_{7}$

$\mathrm{X}_{1} \quad=$ Financial Knowledge

$\mathrm{X}_{2} \quad=$ Risk Tolerance

$\mathrm{X}_{3} \quad=$ Gender

$\mathrm{X}_{4} \quad=$ Age

$\mathrm{X}_{5} \quad=$ Profession

$\mathrm{X}_{6}=$ Last Education

$\mathrm{X}_{7}=$ Monthly Income

$\varepsilon \quad=$ Standard Error

\section{RESULT AND DISCUSSION}

The Indonesia Stock Exchange (IDX) is a party that provides a system as well as a means to bring together securities buying and selling offers from other parties with the aim of trading securities between them. The Indonesia Stock Exchange West Nusa Tenggara Representative Office is one of the capital market development centers for the NTB region and its surroundings which aims to introduce and bring IDX services closer to local governments, agencies, professional 
associations and the public in West Nusa Tenggara Province. Through the Representative Office in NTB, precisely in Mataram City, IDX carries out various program activities to realize these goals by carrying out various Capital Market socialization and education activities to the public in the form of Capital Market Schools, socialization to institutions, Savings Stock Village and various other programs that have been running effectively and continuously.

The Capital Market School is a program held by the IDX to provide education to the general public about matters relating to the capital market and investment. The Capital Market School is divided into two levels and two types (regular capital market schools and Islamic capital market schools). SPM level 1 generally provides an overview related to the world of capital markets such as the introduction of the capital market, trading mechanisms on the stock exchange, listed company mechanisms, etc. This SPM level 2 will explain in detail regarding valuing the stocks that are chosen to invest in the capital market with historical analysis and fundamental analysis to investors who already have an account in the selected securities.

This Capital Market School can be used as a vehicle for the general public to increase their knowledge about the world of the capital market itself and can be used as a first step to prepare themselves to enter the capital market. SPM itself is free of charge, with the condition that to become a capital market participant for level 1 is only an Identity Card (KTP), and for SPM level 2 has opened a securities account in securities which in the future can be used to start stock transactions. The SPM participants will get a certificate from the stock exchange which indicates that the participants have attended the capital market school.

Respondents who have attended the Capital Markets School and have single investor identification (SID) at the Indonesia Stock Exchange Representative Office of West Nusa Tenggara, where $n=110$ respondents were collected in this study. The following table shows the average distribution of the questionnaires to find out the average distribution of respondents' responses to the questionnaire distributed through categorizing the average score to make it easier to analyze respondents' answers. One hundred fifty copies of the questionnaire were distributed or $100 \%$. The questionnaires returned within the specified time limit were 123 copies or $86.33 \%$ of the total questionnaires that had been distributed. Questionnaires that were returned but did not meet the requirements for analysis were 13 copies or $13 \%$ of the total distributed questionnaires. The questionnaires that were returned and met the requirements for analysis were 110 copies or 73.33\%. The sample data obtained are 110 investors consisting of investors who have invested in the Indonesia Stock Exchange and have attended the Capital Market School (SPM) at both level 1 and level 2 by including their SID. Investors who become the sample are also respondents who fill out the questionnaire in this study.

Table 1. Descriptive Statistical Results

\begin{tabular}{lccccc}
\hline \multicolumn{1}{c}{ Variable } & N & Statements & $\begin{array}{c}\text { Mean } \\
\text { Minimum }\end{array}$ & $\begin{array}{c}\text { Mean } \\
\text { Maximum }\end{array}$ & Mean All \\
\hline Investment Decision Making & 110 & 10 & 4.073 & 4.273 & 4.179 \\
Financial Knowledge & 110 & 12 & 4.127 & 4.291 & 4.190 \\
Risk Tolerance & 110 & 12 & 3.800 & 4.100 & 3.944 \\
\hline
\end{tabular}

Source: Research Data, 2020

Based on Table 1, the investment decision-making variable has an overall mean value of 4.179. It shows that investors who are respondents in this study have a good appreciation. Statement number one is a statement with the highest score by an average of 4.273 , containing 
investment in the stock market is attractive. In contrast, the lowest average on the value of 4.073 is statement number five which provides for investment in the stock market investors more risk low compared to the market in general. Hence, investors want to invest more in the stock market. This indicates that for investors investing in the stock market is an interesting thing.

The financial knowledge variable has an overall mean of 4.190. This value indicates that investors who are respondents in this study have a good appreciation of financial knowledge. Statement number 11 is a statement that has the highest score by an average of 4.291 , which provides investors will follow market information to make investment decisions. In contrast, the lowest average on the value of 4.127 is statement number six, which contains investor's decision to retain the stock impaired influenced by information about the stock. Financial knowledge indicators that have the highest average value indicate that investors will follow market information in making investment decisions.

The risk tolerance variable has an overall average of 3.944. This value indicates that investors who are respondents in this study have a good appreciation of financial knowledge. Statement number eight is a statement that has the highest score by an average of 4.100 , which contains risk preferences of investors based on the profits or losses obtained on their investment. In contrast, the lowest average on the value of 3.800 is statement number two, which shows that investors choose investment on the entire instrument in the capital market. The risk tolerance indicator with the highest average value indicates that the investor's risk preference is based on the gains or losses that investors have received on previous stock investments.

Most of the investors are male with a total of 79 people or $71.82 \%$ compared to female investors as many as 31 people or $28.18 \%$. These data indicate that men have an important role in making investment decisions. Investors who have made the decision to invest in stocks have the courage to take risks so they can make decisions faster. This shows that investors who are on the Indonesia Stock Exchange Representative Office of West Nusa Tenggara who have investment decisions based on financial knowledge and risk tolerance are male, where men who have the courage to take risks and have sufficient knowledge so that decision-making be faster.

The age group of respondents who ranged from 24 years and the age group of 25 to 29 years had the same number of 19 people (17.27\%), the age group of 30 to 34 years was 28 people $(25.45 \%)$, the age group was 35 to 34 years. 39 years as many as 26 people (23.64\%), the age group 40 to 44 years as many as 12 people $(10.91 \%)$ and the age group ranging from 45 years as many as 6 people $(5.45 \%)$. Investors who mostly have an age range of 30-34 years with a total of 28 people or $25.45 \%$ of the total respondents indicate that investors with an age range of 30-34 years already have experience and knowledge related to investing in the stock market.

The work group of respondents who work as entrepreneurs is 21 people (19.09\%), the work group as private employees is 38 people or $34.55 \%$, the work group in BUMD/BUMS/PNS is 27 people or $24.55 \%$, the work group as a student is 22 people or $20.00 \%$ and the work group, etc., (mention) as many as 2 people or $1.82 \%$ who are housewives. Most of the investors who are respondents in this study have jobs as private employees with a total of 38 people or $34.55 \%$ of the total respondents. This shows that investors who work as private employees have a high desire to invest in the stock market.

Most of the investors who became respondents in this study had the latest educational background of Bachelor as many as 73 people or $66.36 \%$ of the total respondents. Most investors 
think that their Bachelor (S1) education is sufficient to become a source of knowledge in investing in the stock market.

Income group per month respondents who are in the group Rp2,500,000 as many as 20 people (18.18\%), group $\mathrm{Rp} 2,500,000-\mathrm{Rp} 5,000,000$ as many as 35 people or $31.82 \%$, group

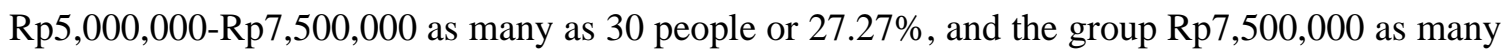
as 25 people or $22.73 \%$. Most of the investors who are respondents in this study have a monthly income of Rp2,500,000-Rp5,000,000 with a total of 35 people or $31.82 \%$ of the total respondents. This shows that investors with these incomes have a high desire to invest in the stock market.

Table 2. Validity Test Results

\begin{tabular}{lccc}
\hline \multicolumn{1}{c}{ Variables } & $\mathbf{R}_{\text {count }}$ & Sig. & Result \\
\hline Financial Knowledge & $0.825-0.909$ & 0.000 & Valid \\
Risk Tolerance & $0.355-0.811$ & 0.000 & Valid \\
Investment Decision Making & $0.806-0.875$ & 0.000 & Valid \\
\hline
\end{tabular}

Source: Research Data, 2020

Validity testing is done by looking at the Pearson Correlation value. The questionnaire items in this study were 32 statements. The results of the validity test can be seen in Table 2 . The validity test is measured using the Pearson Correlation test. If the correlation of each indicator is 0.30 and above and if the arithmetic significance value is less than 0.05 , then the instrument is valid (Sugiyono, 2013). The validity test results indicate that the research instrument consisting of statements of financial knowledge, risk tolerance, and investment decision-making items is valid. Because the correlation of each indicator is 0.30 and above, and the calculated significance value is less than 0.05 .

Table 3. Reliability Test Result

\begin{tabular}{lcl}
\hline \multicolumn{1}{c}{ Variables } & Cronbach's Alpha & Result \\
\hline Financial Knowledge & 0.783 & Reliable \\
Risk Tolerance & 0.750 & Reliable \\
Investment Decision Making & 0.785 & Reliable \\
\hline Source: Research Data, 2020
\end{tabular}

The reliability test is used to measure the consistency of the measuring instrument in measuring the consistency of the respondents in answering each question in the questionnaire. The reliability test was measured using the Cronbach Alpha statistical test. A variable is declared reliable if the Cronbach Alpha value is more than 0.70 (Ghozali, 2013). The reliability test results show that the Cronbach's Alpha coefficient of all variables is more than 0.70 , so it can be said that all of these variables are reliable and suitable to be used as a measuring instrument for the questionnaire instrument in this study.

The coefficient of determination (Adjusted $\mathrm{R}^{2}$ ) is used to measure how far the model's ability to explain variations in endogenous variables. The value of the coefficient of determination is between zero and one. If the value of Adjusted $\mathrm{R}^{2}$ is small, it means that the ability of exogenous variables to explain variations in endogenous variables is very limited (Ghozali, 2013). The coefficient of determination shows how far the model's ability to explain variable variations. The results of this study have an adjusted $\mathrm{R}^{2}$ of 0.557 . It means that this research model can explain $55.7 \%$ of the success model of the independent variable in explaining the applied dependent variable. Other factors outside this model influence the remaining $44.3 \%$. 
Table 4. Multiple Linear Regression Results

\begin{tabular}{clccc}
\hline Model & & B & T & Sig. \\
\hline 1 & (Constant) & 0.223 & 0.520 & 0.604 \\
& Financial Knowledge (X1) & 0.442 & 6.796 & 0.000 \\
& Risk Tolerance (X2) & 0.574 & 5.821 & 0.000 \\
& Gender (X3) & 0.009 & 0.101 & 0.920 \\
& Age (X4) & 0.033 & 0.764 & 0.447 \\
& Proffesion (X5) & -0.019 & -0.463 & 0.645 \\
& Last Education (X6) & -0.006 & -0.086 & 0.932 \\
& Monthly Income (X7) & -0.083 & -1.581 & 0.117 \\
\hline
\end{tabular}

Source: Research Data, 2020

From the results of multiple linear regression using SPSS, the following regression equation is obtained:

$$
Y=0.223+0.442 X_{1}+0.574 X_{2}+0.009 X_{3}+0.033 X_{4}-0.019 X_{5}-0.006 X_{6}-0.083 X_{7}+\varepsilon
$$

From the above equation, it can be explained that the constant is 0.223 , which means that if the independent variable is considered constant, investment decision-making will increase by 0.223 . The financial knowledge regression coefficient of 0.442 shows that if other variables are held constant for each additional financial knowledge, then investment decision-making will increase by 0.442 . The risk tolerance regression coefficient of 0.574 shows that if other variables are considered constant for each additional risk tolerance, the investment decision-making will increase by 0.574 . The gender regression coefficient of 0.009 shows that for each additional gender if the other variables are held constant, the investment decision-making will increase by 0.009 . The age regression coefficient of 0.033 shows that if other variables are held constant for every different age, the investment decision-making will increase by 0.033 . The job regression coefficient of 0.019 shows that if other variables are held constant for each additional job, the investment decision-making will decrease by 0.009 . The job regression coefficient of -0.006 shows that for each additional level of education, if other variables are held constant, then investment decisionmaking will decrease by 0.006 . The regression coefficient of income per month is -0.083 , which shows that for each additional income per month if other variables are held constant, investment decision making will decrease by 0.083 .

The $\mathrm{F}$ test basically determines the effect of the independent variables included in the model on the dependent variable (Ghozali, 2013). If the calculated $\mathrm{F}$ value $<$ significance 0.05 , the model can be used in the regression model. To see the effect of financial knowledge and risk tolerance simultaneously on investment decision-making. The goodness of fit test shows the ANOVA test or F test, which obtained an F count of 20.559 with a probability of 0.000 . The regression model can be used because the calculated $\mathrm{F}$ value is greater than the F table (1.78) and the probability (significance) is much smaller than 0.05 . In other words, it can be concluded that financial knowledge and risk tolerance affect investment decision-making.

The first hypothesis proposed in this study is that financial knowledge positively influences investment decision-making. The test results on this first hypothesis have a $t$ count value of 6.796 , while the $t$ table value at a significance level of $5 \%$ is 1.671 . The $t$ count value on financial knowledge is greater than the $t$ table value, and the significance value is $0.000<0.05$. It is in line with the hypothesis that has been formulated so that the first hypothesis (H1) is accepted. 
The results of this study are in line with the results of research conducted by Akhtar \& Das (2019), which states that the more financial knowledge they have, they can influence investors to make investment decisions. Besides that, Baker et al. (2019) show the need for an essential role from investors to involve their knowledge to make investment decisions. Research results from Wang (2009) and Bettman \& Sujan (1987) also show that financial knowledge consisting of objective knowledge and subjective knowledge is needed when making investment decisions.

The acceptance of the first hypothesis shows that financial knowledge can be seen from the objective norms and subjective norms. All decisions that underlie investors from objective norms are purely from information obtained after conducting various analyses beforehand, both fundamental and technical analyses. Analyzing stock preferences carefully and then considering past stock trends in deciding their investment is essential to their knowledge. While the subjective norms intended in investing, investors tend to follow the decisions of other investors. The reaction taken by an investor who has subjective knowledge feels that he believes that other investors' skills and knowledge can help him decide on a suitable investment for him. Financial knowledge is the basis for processing the reasoning owned by investors to determine the actions taken according to their needs to avoid decision-making mistakes, as stated in the behavioral finance theory.

Gender characteristics in this study amounted to $71.82 \%$, dominated by men compared to women meaning that men have an important role in making investment decisions. These investment decisions cannot be taken if they do not have adequate financial knowledge. The level of education and maturity have seen from age can be the basis that the decisions taken have led to the right decisions. This can be seen from the number of respondents who are dominated by the latest undergraduate education level of $64.55 \%$ and the dominance of age in the range of 30-34 years by $25.45 \%$.

The information obtained will be essential and consideration when investing. Financial knowledge has meaning for investors because it has facts, which are helpful both now and in the future. There is a process of transforming knowledge into information that is input-process-output. Information as a material/tool in decision making, of course, must have good knowledge. Output in the form of decisions generated by the knowledge possessed will be considered in making investments. Evaluation of the knowledge capabilities possessed in investment decisions will be helpful if they can address opportunities and deal with problems that arise in investing in the stock market.

The second hypothesis proposed in this study is suspected that risk tolerance positively influences investment decision-making. The test results on this second hypothesis also have a count value of 2.865 , while the $t$ table value at a significance level of $5 \%$ is 1.671 . The $t$ count value for risk tolerance is greater than the table value, and the significance value is $0.000<0.05$. It is in line with the hypothesis that has been formulated so that the second hypothesis (H2) is accepted.

The results of this study support previous research from Wulandari \& Iramani (2014) that risk tolerance can affect the investment decision-making of economics lecturers. Falahati \& Paim (2012) also revealed that risk tolerance varies from gender and age; investors who have risk tolerance tend to invest in instruments with high risk. Research is also in line with Ramudzuli \& Muzindutsi (2018), Duong \& Huong (2017), and Pak \& Mahmood (2015), which shows that risk tolerance affects investment decisions. 
The acceptance of the second hypothesis illustrates that each investor's risk tolerance has differences in tolerance levels such as in giving tolerance which can be caused by differences in age, career status, socio-economic, income, wealth, and income prospects so that risk tolerance influences decision-making. Investors with high-risk tolerance strive to get optimal profits by their risk tolerance so that they are optimal. Investors need to pay attention to information about the company's reputation, referral information from friends who understand investment instruments or brokers, and information on the ease of reselling their shares. The various levels of risk tolerance cannot be separated because the psychology of every human being is different. Behavioral finance theory states that human action in making investment decisions can be appropriate if the investor can know the risk profile.

Based on behavioral finance theory, risk tolerance is an individual investor who takes action in financial activities. Different levels of investor tolerance for risk influence investment decision-making behavior. This behavior depends on the risk profile of each investor with investor preference for the type of investor who is risk seeker, risk-neutral, or risk averter.

Private employees dominated the characteristics of the work background in this study at $34.55 \%$. Whatever background investors are involved in cannot change their risk tolerance. This means that an investor must know which type of investor they are to make the right decision according to their tolerance.

Investors with a profile that tends to be a risk seeker will be willing to buy high-risk investments in high-quality stock instruments to get high profits. Investors with a risk seeker profile will be more willing to seek and accept risk than usual when faced with the possibility of more significant losses. Investors with a profile that tends to be risk-neutral will assume that risk always leads to losses. This investor is more calculating the profits and losses on the investment stock portfolio owned. This investor's risk preference is based on the gains and losses made on previous stock investments and avoids selling stocks whose value declines. Investors with a riskaverter profile will be careful in deciding to invest in the stock market. Investors will invest in various quality stock instruments from low to high. This type will also immediately sell stocks that increase in value more quickly.

\section{CONCLUSION AND RECOMMENDATION}

This study was conducted to empirically test the relationship between financial knowledge and risk tolerance for investment decision-making on investors. The investors have attended the capital market school at the Indonesia Stock Exchange Representative Office of West Nusa Tenggara and already have a single investor identification (SID). The data used in this research is primary data through questionnaires given to respondents who meet the criteria. Based on the results of the analysis and discussion, the following conclusions can be drawn : (1) Financial knowledge has a positive effect on investment decision making, and (2) Risk tolerance has a positive effect on investment decision making. The results of this study have implications for investors; namely, investors must pay more attention to the financial knowledge and recognize the type of risk profile in the investor. Investors must also predict uncertain stock investment conditions in the future and manage risk properly to provide the expected return on their investment. 
This study is inseparable from its shortcomings, and the authors view that the control variables used in this study can be used further. In addition, the distribution of this research questionnaire does not reach areas outside the city of Mataram because the coverage of the province of West Nusa Tenggara consists of Lombok Island and Sumbawa Island. For further writers, the authors suggest continuing this research to a broader and deeper stage to obtain more complete results and detailed results, such as using measuring instruments with experimental methods or interviews with respondents.

\section{REFERENCES}

Akhtar, F., \& Das, N. (2019). Predictors of investment intention in Indian stock markets: Extending the theory of planned behaviour. International Journal of Bank Marketing, 37(1), 97-119.

Alba, J. W., \& Hutchinson, J. W. (2000). Knowledge Calibration: What Consumers Know and What They Think They Know. Journal of Consumer Research, 27(2), 123-156.

Bailey, J. J., \& Kinerson, C. (2005). Regret avoidance and risk tolerance. Journal of Financial Counseling and Planning, 16(1), 23-28.

Baker, H. K., Kumar, S., Goyal, N., \& Gaur, V. (2019). How Financial Literacy and Demographic Variables Relate to Behavioral Biases. Managerial Finance, 45(1), 146-168.

Bettman, J. R., \& Sujan, M. (1987). Effects of Framing on Evaluation of Comparable and Noncomparable Alternatives by Expert and Novice Consumers. Journal of Consumer Research, 14(2), 141-154.

Bodie, Z., Kane, A., \& Marcus, A. J. (2014). Manajemen Portofolio dan Investasi 1. Salemba Empat.

Calvet, L., Célérier, C., Sodini, P., \& Vallée, B. (2016). Financial Innovation and Stock Market Participation. Canadian Derivatives Institute.

Duong, N. T., \& Huong, T. T. T. (2017). The Analysis of Major Credit Risk Factors - The Case of the Vietnamese Commercial Banks. International Journal of Financial Research, 8(1), 33 42.

Falahati, L., \& Paim, L. H. (2012). Experiencing Financial Problems Among University Students: An Empirical Study on the Moderating Effect of Gender. Gender in Management, 27(5), $315-330$

Fuller, R. J. (2000). Behavioral Finance and The Sourse of Executive. BSI Gamma Foundation.

Ghozali, I. (2013). Aplikasi Analisis Multivariate Dengan Program IBM SPSS 21 Update PLS Regresi. Universitas Diponegoro.

Goldsmith, R. E., \& Goldsmith, E. B. (2016). The Effects of Investment Education on Gender Differences in Financial Knowledge. Journal of Personal Finance, 5(2), 55-69.

Grable, J., \& Lytton, R. H. (1999). Financial Risk Tolerance Revisited: The Development of a Risk Assessment Instrument. Financial Services Review, 8(3), 163-181.

Kannadhasan, M. (2015). Retail Investors' Financial Risk Tolerance and Their Risk-taking Behaviour: The Role of Demographics as Differentiating and Classifying Factors. IIMB Management Review, 27(3), 175-184.

Lintner, J. (1969). The Valuation of Risk Assets and the Selection of Risky Investments in Stock Portfolios and Capital Budgets: A Reply. The Review of Economics and Statistics, 51(2), $222-224$ 
Marsh, B. A. (2006). Examining the Personal Finance Attitudes, Behaviors, and Knowledge Levels Of First-Year and Senior Students at Baptist Universities In The State Of Texas. Higher Education Ph.D. Dissertations.

Mazumdar, S. (2014). Individual Investment Behaviour with Respect To Financial Knowledge And Investment Risk Preference: A Study. International Journal on Management Research and Business Strategy, 3(2), 47-55.

Natapura, C. (2009). Analisis Perilaku Investor Institusional dengan Pendekatan Analytical Hierarchy Process (AHP). Bisnis \& Birokrasi: Jurnal Ilmu Administrasi Dan Organisasi, 16(3), 180-187.

Pak, O., \& Mahmood, M. (2015). Impact of Personality on Risk Tolerance and Investment Decisions: A Study on Potential Investors of Kazakhstan. International Journal of Commerce and Management, 25(4), 370-384.

Ramudzuli, P. M., \& Muzindutsi, P. F. (2018). Determinants of Financial and Non-Financial Risk Tolerance among Students at Selected South African Universities. Foundations of Management, 10(1), 293-302.

Sahi, S. K., Arora, A. P., \& Dhameja, N. (2013). An Exploratory Inquiry into the Psychological Biases in Financial Investment Behavior. Journal of Behavioral Finance, 14(2), 94-103.

Sugiyono. (2013). Metode Penelitian Pendidikan (Pendekatan Kuantitatif, Kualitatif, dan R\&D). Alfabeta.

Wang, A. (2009). Interplay of Investors' Financial Knowledge and Risk Taking. Journal of Behavioral Finance, 10(4), 204-213.

Wattanasuwan, K. (2005). The Self and Symbolic Consumption. Journal of American Academy of Business, 6(1), 179-184.

Wulandari, D. A., \& Iramani, R. (2014). Studi Experienced Regret, Risk Tolerance, Overconfidance dan Risk Perception Pada Pengambilan Keputusan Investasi. Journal of Business and Banking, 4(1), 55-66. 